Roksandić I.Branka ${ }^{1}$,

Delić S. Branislava²,

Aracki S. Nenad ${ }^{2}$,

Petrović D. Radmila ${ }^{1}$

${ }^{1}$ Emergency Center, Clinical Center of Vojodina, Novi Sad Hajduk Veljkova 1-7,

${ }^{2}$ Emergency Medical service Novi Sad, Novi Sad, Bulevar Patrijarha Pavla 26a

\section{Acute poisoning as urgent cases and care measures}

\begin{abstract}
Introduction: Patients with acute poisoning constitute $3-5 \%$ of patients treated by emergency physicians.

Aim of the study: Determine frequency and etiology of acute poisoning, and factors affecting the outcome.

Materials and methods: A retrospective, observational study enrolled patients who were treated by teams of the Emergency Medical Service Novi Sad (EMS) in the period from 01.01.2011. to 31.12.2011. due to acute poisoning. Further diagnostics and therapy were implemented in the Emergency Center (EC).
\end{abstract}

Results: 226 patients with symptoms of acute poisoning were included (53.5\% men, $46.5 \%$ women). The average patient age was 37.1 years. The principal mode of toxins entry was oral (87.6\%). Alcohol poisoning was present in $29.2 \%$, benzodiazepines in $23.5 \%$, combination of alcohol and psychotropic drugs in $14.2 \%$ of cases. Prehospital, infusion therapy was initiated in $31 \%$, Naloxone ${ }^{\circledR}$ was given in $10.6 \%$ and flumazenil (Anexate ${ }^{\circledR}$ ) in $6.2 \%$ patients. After detoxication measures and observation $76.5 \%$ of patients were referred to psychiatric evaluation. $0.9 \%$ of cases had a fatal outcome.

Conclusion: Since successful treatment of acute intoxication depends on the quality of initial care, efficient access to EMS, identification of poisoning etiology (toxic substances), and implementation of non-specific treatment (provided the airway, infusion therapy, vomiting provocation) is a good basis for further treatment at hospital level. 


\section{Introduction:}

Acute poisoning appears as consequence of short-term exposure to toxic substances. It results from a single or multiple exposure to toxic substances during short period of time (usually within 24 hours). Poisoning can be accidental or suicidal. Suicidal poisonings are major public health problems in developed countries. Namely, poisoning is the leading method of suicide attempts. Problems in diagnostics and therapy are the result of the fact that patients can have a wide range of different symptoms often changing over time. History of these people is unreliable, they often exaggerate or minimize suicide attempt and some substances cause amnesia. Intoxicated who initially have mild symptoms can get in life-threatening condition. Therefore, observation is necessary until this condition is excluded on the basis of clinical findings and laboratory tests $[3,4]$.

Treatment of poisoned patients in out-ofhospital conditions consists of: maintance of vital functions, identification of causes of poisoning, vomiting provocation. This is basis for further treatment. At hospital level measures to prevent poison absorption include: use of activated charcoal, gastric lavage and forced laxation. Natural elimination accelerate: Repeated use of activated charcoal, forced diuresis and hyperventilation accelerate natural elimination. Artificial detoxification procedures are: hemodyalisis, hemoperfusion and plasmapheresis. A small number of toxins has a specific antidote, therefore we generally treat poisoning symptomatically. Nacional centres for poisoning provide help in treatment, suggesting a therapeutic plan in individual cases. Also, these centres have data about various causes of poisoning and can arrange a variety of diagnostic tests $[2,4]$.

\section{Aim of the study:}

Determine frequency and etiology of acute poisoning, age and gender structure of the acutely intoxicated, and factors affecting the outcome.

\section{Material and methods:}

A retrospective, observational study enrolled patients with acute poisoning treated by teams of the Emergency Medical Service Novi Sad (EMS) in the period from 1.1.2011. to 31.12.2011. Further diagnostics and therapy were implemented in the Emergency Center (EC). Data were collected from protocols of the patients from Institute for Emergency medicine Novi Sad and from EC database. Data taken from the protocols were: age, gender and vital parameters of the patients, and applied therapy. Data taken from the database were: type of the toxic substance, applied therapy and the direction of referral patients from the emergency toxicology department. Results were analysed using package Statistica 7 and SPSS 11 and presented in tables and graphs.

\section{Results:}

In the one-year period emergency teams of Institute for Emergency Medicine Novi Sad treated 37.780 patients. 226 $(0,60 \%)$ patients were transported after initial treatment to the $\mathrm{EC}$ with diagnosis of acute poisoning.

The highest number of cases of acute poisonig was noted in January and May (Graph 1). 


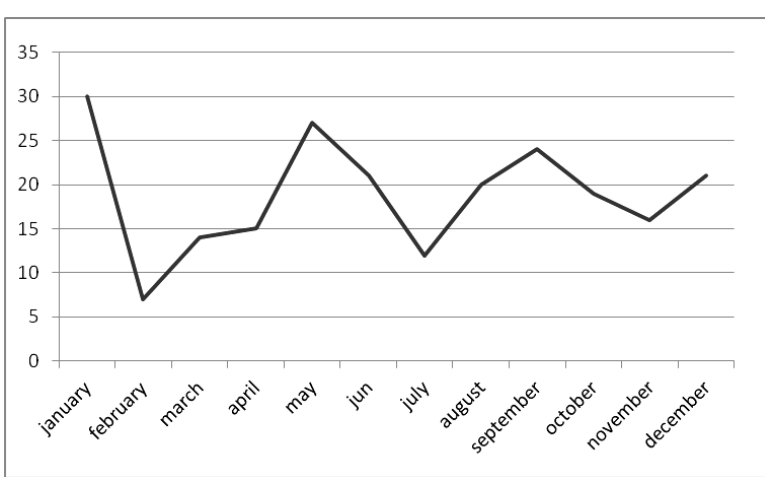

Graph 1. Frequency of acute poisoning during year

There was no statistically significant difference in frequency of acute poisoning between men and women $(\chi 2=1,284$, $\mathrm{p}>0,05)$ (Graph 2).

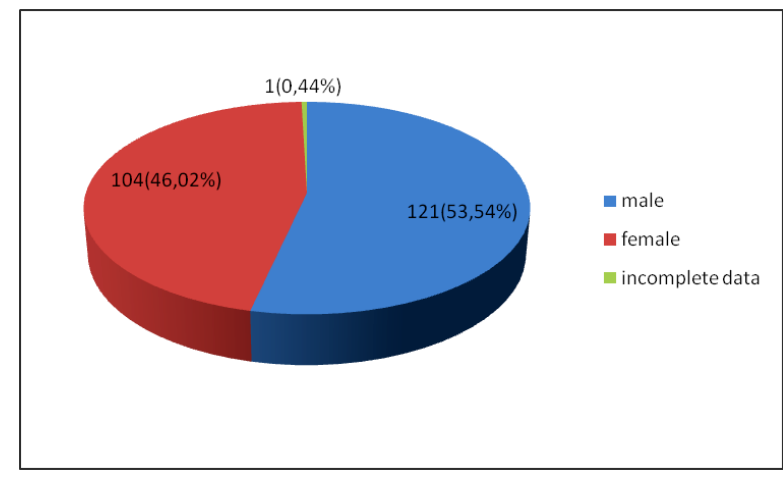

Graph 2. Gender structure of acute poisoning

The average age of our patients was 37.10 years ( $\mathrm{SD} \pm 14,37$, Me 34, $\min 18, \max 95$ ). The average age of male patients was 35 ( $\mathrm{SD} \pm 13,99$, Me 31, min 18, $\max 95)$, and female 39,58 ( $\mathrm{SD} \pm 14,47$, Me 38, $\min 18$, $\max 77)$. There was statistically significant difference in the age between men and women $(p \leq 0,05)$. In majority of our patients the input path of toxic substance was oral. (Graph 3).

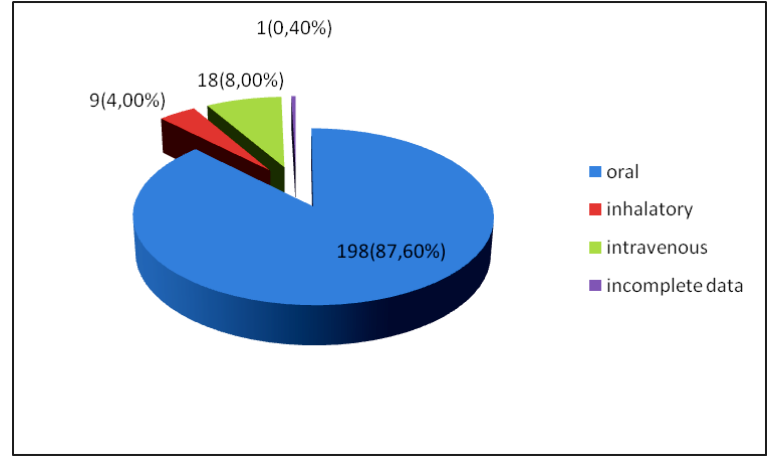

Graph 3. Input path of toxic substances

The most frequent cause of poisoning was alcohol in $66(29,20 \%)$ cases. Among medications the most frequent cause of poisoning were benzodiazepines -53 $(23,45 \%)$ cases. Opioids were causes of poisoning in $28 \quad(12,39 \%)$ and amphetamines in $2(0,88 \%)$ of cases (Table $1)$.

Table 1 Etiology of acute poisoning

\begin{tabular}{|c|c|c|}
\hline Etiology & Number & $\%$ \\
\hline Alcohol & 66 & 29,20 \\
\hline Opioids (heroin, methadone) & 28 & 12,39 \\
\hline Benzodiazepines & 53 & 23,45 \\
\hline $\begin{array}{l}\text { Psychiatric drugs } \\
\text { (antidepressants, antipsychotics) }\end{array}$ & 10 & 4,42 \\
\hline $\begin{array}{l}\text { Psychostimulants } \\
\text { (Amphetamines) }\end{array}$ & 2 & 0,88 \\
\hline $\begin{array}{l}\text { Alcohol, psychiatric drugs } \\
\text { (benzodiazepines, } \\
\text { antidepressants, antipsychotics) }\end{array}$ & 32 & 14,16 \\
\hline $\begin{array}{l}\text { Benzodiazepines, NSAID, } \\
\text { Alcohol }\end{array}$ & 4 & 1,77 \\
\hline $\begin{array}{l}\text { Benzodiazepines, psychatric } \\
\text { drugs }\end{array}$ & 4 & 1,77 \\
\hline $\begin{array}{l}\text { Psychiatric, cardiovascular } \\
\text { drugs }\end{array}$ & 8 & 3,55 \\
\hline Cardiovascular drugs & 2 & 0,88 \\
\hline Gaseos (smoke, $\mathrm{CO}, \mathrm{CO} 2$ ) & 7 & 3,10 \\
\hline Pesticides & 6 & 2,66 \\
\hline Incomplete data & 4 & 1,77 \\
\hline Total & 226 & 100 \\
\hline
\end{tabular}


In men the most common cause of acute poisoning in men was alcohol $47(39,50 \%)$, and the second were opioids. Women were poisoned predominantly with benzodiazepines $-35(34,32 \%)$ cases, and with antidepressants and antipsychotics 9 $(8,82 \%)$ cases.

The most frequent combination of toxic substances in both gender was alcohol plus psychiatric drugs. This combination was present in $13(10,92 \%)$ men, and 19 $(18,63 \%)$ women (Table 2).

Table 2. Distribution of causes of poisoning by gender

\begin{tabular}{|l|c|c|c|c|}
\hline Etiology & $\begin{array}{c}\text { Male } \\
\text { number }\end{array}$ & $\%$ & $\begin{array}{c}\text { Female } \\
\text { number }\end{array}$ & $\%$ \\
\hline Alcohol & 47 & 39,50 & 19 & 18,63 \\
\hline $\begin{array}{l}\text { Opioids } \\
\text { (heroin, methadone) }\end{array}$ & 23 & 19,33 & 4 & 3,92 \\
\hline Benzodiazepines & 18 & 15,13 & 35 & 34,32 \\
\hline $\begin{array}{l}\text { Psychiatric drugs } \\
\text { antidepressants, } \\
\text { antipsychotics) }\end{array}$ & 1 & 0,84 & 9 & 8,82 \\
\hline $\begin{array}{l}\text { Psychostimulants } \\
\text { Amphetamines) }\end{array}$ & 1 & 0,84 & 1 & 0,98 \\
\hline $\begin{array}{l}\text { Alcohol,psychiatric } \\
\text { drugs (benzodiazepines, } \\
\text { Antidepressants, } \\
\text { antipsychotics) }\end{array}$ & 13 & 10,92 & 19 & 18,63 \\
\hline $\begin{array}{l}\text { Benzodiazepines, } \\
\text { NSAID, Alcohol }\end{array}$ & 1 & 0,84 & 3 & 2,94 \\
\hline $\begin{array}{l}\text { Benzodiazepines, } \\
\text { psychiatric drugs }\end{array}$ & 1 & 0,84 & 3 & 2,94 \\
\hline $\begin{array}{l}\text { Psychiatric,cardiovascul } \\
\text { ar drugs }\end{array}$ & 1 & 0,84 & 7 & 6,86 \\
\hline Cardiovascular drugs & 1 & 0,84 & 1 & 0,98 \\
\hline $\begin{array}{l}\text { Gases (smoke, CO, } \\
\text { CO2) }\end{array}$ & 7 & 5,88 & 0 & 0 \\
\hline Pesticides & 5 & 4,20 & 1 & 0,98 \\
\hline Total & 119 & 102 & 100 \\
\hline $\begin{array}{l}\text { Incomplete data } \\
\text { (1) }\end{array}$ & 500 & \\
\hline
\end{tabular}

Gastric lavage was performed in 157 $(69,47 \%)$ cases of acute poisoning (Graph 4).

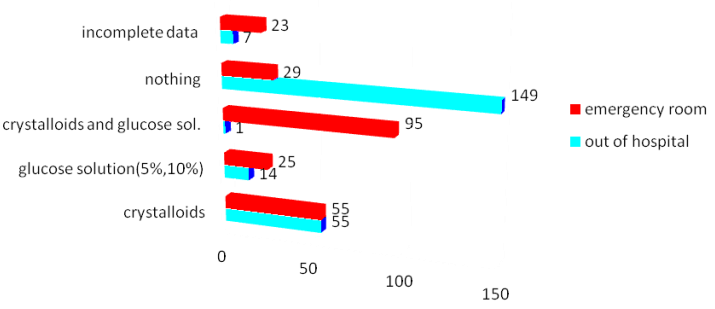

Graph 5. The use of infusion solutions

Only two antidotes: were used: flumazenil

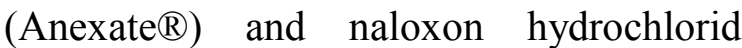
(Naloxon $\left.{ }^{\circledR}\right)($ Graph 6).

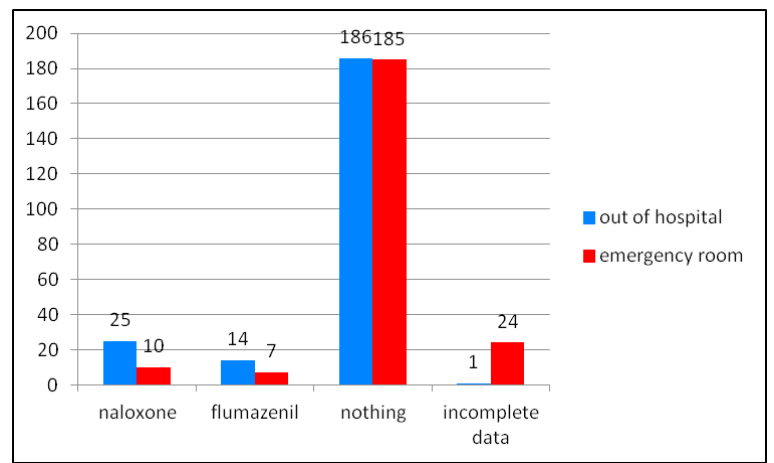

Graph 6. The use of antidotes 
After detoxication measures performed in Emergency Center high percent of our patient $(76.55 \%)$ were refered to a psychiatrist for further evaluation (Graph 7).

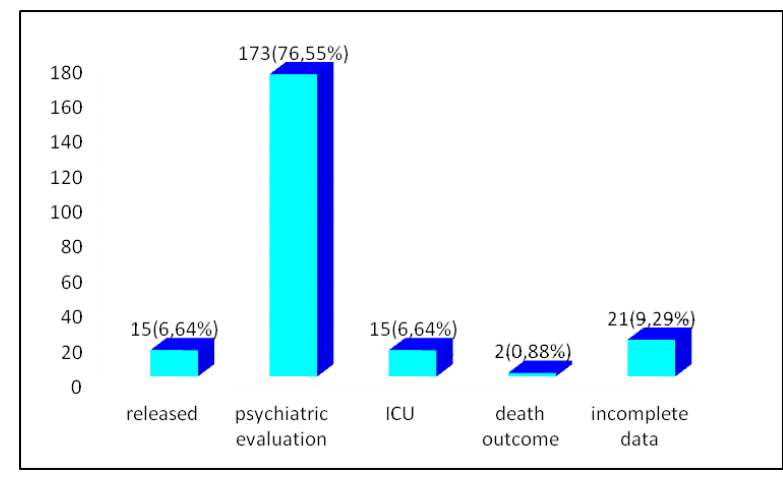

Graph 7. The outcome of acute poisoning treatment in Emergency Center

Several factors influenced the outcome (Table 3).

Table 3. Spearman correlation coefficient between the outcome of treatment at urgent admission AT and influencing factors $(\mathrm{p} \leq 0.05)$

\begin{tabular}{|l|l|}
\hline Variables & outcome \\
\hline Month & $-0,111093$ \\
\hline Day & $-0,093663$ \\
\hline Age & 0,13893 \\
\hline Gender & 0,097663 \\
\hline The path of entry & $-0,00448$ \\
\hline cCause & 0,150428 \\
\hline Consciousness / on the field & 0,136327 \\
\hline Systolic pressure / on the field & $-0,203598$ \\
\hline Diastolic pressure / on the field & $-0,245195$ \\
\hline Saturation / on the field & $-0,238234$ \\
\hline Oxygen / on the field & $-0,174024$ \\
\hline fluids / on the field & $-0,155931$ \\
\hline Antidote / on the field & $-0,023876$ \\
\hline $\begin{array}{l}\text { Consciousness / admission to } \\
\text { hospital }\end{array}$ & 0,178674 \\
\hline $\begin{array}{l}\text { Systolic pressure / admission to } \\
\text { hospital }\end{array}$ & $-0,038424$ \\
\hline $\begin{array}{l}\text { Diastolic pressure / admission to } \\
\text { hospital }\end{array}$ & $-0,112054$ \\
\hline Pulse / admission to hospital & $-0,100512$ \\
\hline $\begin{array}{l}\text { Saturation / admission to } \\
\text { hospital }\end{array}$ & $-0,136065$ \\
\hline Gastric lavage & $-0,022264$ \\
\hline Oxygen / admission to hospital & $-0,112492$ \\
\hline Fluids / admission to hospital & $-0,106408$ \\
\hline Antidote / admission to hospital & $-0,048611$ \\
\hline CPR / on the field & $-0,225757$ \\
\hline CPR / admission to hospital & $-0,313101$ \\
\hline
\end{tabular}

\section{Discussion:}

Poisoning remains a significant problem in emergency room, more than 4 milion cases are recorded every year in the USA. Poisoning is the second leading morbidity and mortality cause because of the injury in the USA with estimated costs for health care system about 12,6 bilions $\$$ a year [5].

According to this study, the highest number of poisoning cases is registered in January and May, because of holidays during this period. The most common toxic agent is alcohol. According to the register of poisoning the American College of Medical Toxicology for year 2010/2011, the higest number of poisoning cases is registered during summer and autumn [6]. Italian prospective study, which was carried out in the territory of the northern, central and southern Italy in 2003/2004, shows homogenous distribution of acute poisoning during the year with oscitations in spring [7].

Analysis of the gender structure of the research gave results, which match other European studies. According to the study from Madrid VEIA 2004 and one-year observational study carried out in Oslo for period $2008 / 2009,50 \%$ of the patients were male $[8,9]$. The register of the American College shows similar gender structure [6]. A slightly higher percentage of the male patients is in Italian study $(64,90 \%)$ [7]. According to the study conducted in United Kingdom in 2004 women are dominant patients in the total number of poisoned. This difference of the British study from other studies is because the main toxic agent in United Kingdom are paracetamol and antidepressants, that women more often use [10]. In other European countries the 
main toxic agent is alcohol, traditionally used more often by men.

The average age of patients is similar to the average age of patients in European studies. Oslo study shows that the average age of the poisoned patients is 36 [9]. According to the study for the period 2006/2008 in Netherland, the average age of the patients is 34 [3]. Italians are older, men 40,9 and women 41,8 [7]. Our study shows that women are older. The results of the American study conducted in Chicago from 2004 to 2007 show that the age of the largest number of patients is between 36 and $45[5]$.

The main way of entry of the toxic agent is oral. This is understandable because alcohol and psychiatric drugs are dominant in the atiology of poisoning. The oral way of exposure to the toxic agents is present in $80,90 \%$ cases in the earlier mentioned Italian study [7].

Alcohol is the most often cause of poisoning. This can be explained with the habits of the population, and the fact that alcohol is widely alailable. Alcohol is the leading cause of the poisoning in European countries as well $[3,4,7,8,9]$.

The second leading cause of the poisoning are benzodiazepines. This result of the study can be explained by increasing use of benzodiazepines. Doctors often prescribe these medications, so there is a danger of accidental or intentional poisoning. Benzodiazepines are the second leading cause of the poisoning in the other European countries $[3,4,5,8]$. The Register of poisoniong of the American College shows that the benzodiazepines are the most often cause of the toxicology consultations in 2011 [6]. The leading cause of poisoning in the United Kingdom during 2004. was paracetamol, alone or in the combination with other substances [10]. In our study benzodiazepines, antidepressants and antipsyhotics are the leading cause of the poisoning in women, while men are the most often poisoned with alcohol and opioids. Similar results are in Italy and Norway [7,9].

Our study indicates often use of gastric lavage in the Emergency room. If acutely poisoned person comes in the first two hours from exposure, this measure can be applied. However, gastric lavage is used rarely in European countries. Oslo study shows declining use of gastric lavage (17\% 2003 vs. 9\% 2008). Prospective study from Netherland shows the use of the gastric lavage only in $11,70 \%$ cases of poisoning. According to the Italian prospective multricentric study lavage was used in only $5,2 \%$ of patients $[3,7,11]$. British study from 2004 showed, that treatment of the acute poisoning without use of gastic lavage results with good outcome and low mortality rate. The difference between our and European studies exists because in European countries time of arrival in Emergency room is 3 hours or more. European studies indicated that the good outcome was possible without this relatively agressive procedure that carries the risk of aspiration [7,10,11].

Supportive therapy with fluids was indicated in one third of our patients on the field, and in $78 \%$ of the cases in Emergency room. According to the European studies supportive therapy is applied in $2,1 \%$ cases in Italy, 22,2\% in Netherland, 9,2\% in United Kingdom and in $70 \%$ of cases in Norway $[3,7,10,11]$.

More than $80 \%$ of our patients didn't 
receive antidote. Similar results we can find in studies from Italy $(87,2 \%)$ and Netherlands $(81,5 \%)$. In Oslo study $62 \%$ of patients didn't receive antidote $[3,7,11]$.

In our study naloxone hydrochloride was given more frequently on the field than in the emergency room. Naloxone hydrochloride is competitive antagonist of opioids that removes opioids effects fast. In minority of patients there is a need to repeat dose in the emergency room [12]. Use of flumazenil in only 14 cases on the field and in 7 cases in emergency room, can be explained by nature of this antidote. Flumazenil in patients who use benzodiazepines chronically can precipitate withdrawal syndrome and seizures. In patients poisoned with combination of benzodiazepines and other medications, flumazenil can remove protective effect of benzodiazepines but arythmia and seizures can appear. In European countries doctors decide to use flumazenil in cases of isolated benzodizepine poisoning when the patient was treated for a short period of time. Antidote is used in severe, hemodinamicaly unstable cases of poisoning. According to the Oslo study it is used in $19 \%$, and in Italian study in $12,2 \%$ of cases $[7,11,12]$.

Outcome in the most cases in the emergency room is favorable. Intrahospital mortality is similar to other European countries (0.3 $0.8 \%)[7,11]$.

High percentage of our patients were sent to psychiatric evaluation due to frequent use of psychiatric drugs alone or in combination with alcohol. Another reason is that psychiatric evaluation is a part of the procedure with acutely poisoned people in Emergency Center of Clinical Center of Vojvodina after detoxication and stabilisation. According to our study, the of patients who were admited in ICU (intensive care unit) was not high. This can be explained by applying optimal detoxication measures on the field and in the Emergency room. According to Oslo study $49 \%$ of patients were admitted in ICU, but authors concluded, that use of ICU is liberal, because every fifth patient is comatose. According to British authors $1,7 \%$ of poisoned patients are admitted to ICU $[10,11]$.

Our study showed that the outcome of treatment in emergency room is optimal in following cases: when resustitation measures are applied on the field and in the emergency room, in cases of hemodinamicaly stable patients on the field, and when oxygen therapy and fluids are applied. Some causes of poisoning and disturbance of consciousness in emergency room are in negative corelation with the outcome of treatment in EC of Clinical Center of Vojvodina.

The lack of research is the unavailability of dates about circumstances of poisoning (accidental, suicidal). These data are generally known after psychiatric evaluation. Our study didn't include outcome of patients treated in ICU. Based on these data it is possible to apply preventive measures in acute poisoning.

\section{Conclusion:}

Early out-of hospital applying of supportive therapy with fluids and oxygen is related to an optimal outcome of treatment in the ER. Cooperation of EMS and EC is necessary for quick identification of toxic agent as acute poisoning can be treated succesfully when treatment is started earlier. A great role of psychiatric drugs in the etiology of poisoning demands the need for higher control of prescribing and in this way better regulation of their availability. 


\section{REFERENCES:}

1. Hodgson E, Levi PE. A text book of modern toxicology. 2nd ed. Stamford: Appleton \& Lange; 1997. p. 161-62.

2. Vasović V, Mikov M, Švajcer Đaković K. Selected topics in Toxicology. 2nd ed. Kula: Borac; 2009.p. 1-9.

3. Ambrosius RGA, Vroegop MP, Jansman FGA, Hoedemaekers CW, Aarnoutse RE, Van der Wilt GJ, Kramers C. Acute Intoxication patients Presenting to an Emergency Department in the Netherlands: Admit or Not? Prospective testing two Algorithms. WebMD Medscape Multispecialty [serial on the Internet]. 2012 Jun [cited 2014 Jan] Available from: http:// www.medscape.com/article/765189-overview.

4. Müler D, Desel H. Common causes of poisoning: Etiology, Diagnosis and Treatment. Deutsches Ärzteblatt International. 2013; 110(41): 690-700.

5. Klifi M, Zun L, Johnson G, Harbison R. Etiological characterization of acute poisonings in the emergency department. J Emerg Trauma Schock. 2009; 2(3): 159-63.

6. Wiegand TJ, Wax PM, Schwartz T, Finketstein Y, Gorodetsky R, Brent J. The Toxicology

Investigators Consortium Case Registry-The 2011

Experience. J Med Toxicol. 2012; 8(4): 360-77.

7. Botti P, Cipriani F, Dannaoui B, Bravi S, Missanelli A, gruppo Epinox. Intossicazioni acute e avvelenamenti nei Dipartamenti di Emergenza e Urgenza in Italia. Ann Ist Super Sanita 2006; 42(3): 287-97.

8. Valles Caballero PJ, Pombo Dorado S, Brasero Diaz A, Gil Garsia ME, Salgado Yubero L, et al. Epidemiologic survey of acute poisoning in the south area of the Community of Madrid.The VEIA 2004 study. An Med Interna. 2008; 25(6): 262-68.

9. Lund C, Teige B, Drottning P, Stiksrud B, Rui Olav T, Lyngra $\mathrm{M}$, et al. The one-year observational study of all hospitalized and fatal acute poisonings in Oslo: Epidemiology, intention and follow up. BMC Public Health 2012; 12: 858.

10. Cook R, Allcock R, Johnston M. Self-poisonig: current trends and practice in a UK teaching hospital. Clin Med. 2008; 8(1) 37-40.

11. Lund C, Drottning P, Stiksrud B, Vahabi J,
Lyngra M, Ekeberg I, et al. One-year observational stydy of all hospitalized acute poisonings in Oslo: complications, treatment and sequelae. Scand J Trauma Resusc Emerg Med. 2012; 20: 49.

12. Marraffa JM, Cohen V, Ann Howland M. Antidotes for toxicological Emergencies. WebMD Medscape Multispecialty [serial on the Internet] 2012 februar [cited 2014 jan]. Available from: http:// www.medscape.com/article/757588-overview.
Rad je izlagan u oktobru 2012. godine na kongresu Evropskog Resuscitacionog Saveta u Beču i sažetak je objavljen u zborniku radova. 
Roksandić I.Branka ${ }^{1}$,

Delić S. Branislava²,

Aracki S. Nenad ${ }^{2}$,

Petrović D. Radmila ${ }^{1}$

${ }^{1}$ Urgentni centar, Klinički centar Vojvodine, Novi Sad, ulica Hajduk Veljkova 1-7

${ }^{2}$ Hitna medicinska pomoć Novi Sad, Novi Sad, Bulevar Patrijarha Pavla 26a

\section{Akutna trovanja kao urgentna stanja i mere zbrinjavanja}

\section{Sažetak}

Uvod: Slučajevi akutnog trovanja čine i do $10 \%$ od ukupnog broja pacijenata zbrinutih u urgentnim službama.

Cilj: Prikazati učestalost, etiologiju akutnih trovanja kao i faktore koji utiču na ishod lečenja.

Materijal i metode: Sprovedeno je retrospektivno, opservaciono istraživanje. U istraživanje su uključeni pacijenti koji su u periodu od 1.1.2011. do 31.12.2011. pregledani od strane terenskih ekipa Zavoda za hitnu medicinsku pomoć Novi Sad zbog akutnog trovanja, a zatim transportovani u Urgentni centar Kliničkog centra Vojvodine (UC $\mathrm{KCV}$ ) radi sprovođenja dalje dijagnostike i terapije.

Rezultati: U posmatranom periodu je zbrinuto 226 osoba sa simptomima akutnog trovanja. Prosecna starost akutno otrovanih iznosila je 37,10 godina. 53,54\% osoba bilo je muskog pola. Najčešći put unosa toksina je bio oralni $(87,60 \%)$. Trovanja alkoholom su bila zastupljena u 29,20\%, benzodiazepinima u 23,45\%, kombinacija alkohola i psihofarmaka u $14.16 \%$ slučajeva. Prehospitalno, infuziona terapija je započeta u $30,97 \%$, naloxon je dat kod 10,62\%, a flumazenil kod $6,19 \%$ otrovanih. $6,64 \%$ otrovanih je nakon primene detoksikacionih mera i opservacije u UC KCV otpušteno kući, 76,55\% je upućeno na psihijatrijsku procenu. U 0,88\% slučajeva lečenje je imalo smrtni ishod. Ishod lečenja akutno otrovanih zavisio je od sledećih prehospitalnih faktora: uzroka trovanja, arterijske tenzije, vrednosti kiseonika u kapilarnoj krvi, primene kiseonika i infuzione terapije, te primene mera napredne životne potpore. Stanje svesti i primena naprednih mera životne potpore na prijemu UC KCV su takođe uticali na ishod lečenja.

Zaključak: S obzirom da uspeh lečenja akutno otrovanih zavisi od kvaliteta inicijalnog zbrinjavanja, efikasan pristup ekipa hitne pomoći u cilju identifikacije uzroka i primene nespecifičnih mera lečenja (obezbeđen disajni put, infuziona terapija, provokacija povraćanja, mere resuscitacije) je dobra osnova za dalju terapiju na hospitalnom nivou.

Ključne reči: akutna trovanja, inicijalno zbrinjavanje, nespecifične mere lečenja 